\title{
Botanical identification of medicinal roots collected and traded in Morocco and comparison to the existing literature
}

\author{
Abderrahim Ouarghidi ${ }^{1,2^{*}}$, Gary J Martin², Bronwen Powell ${ }^{3}$, Gabrielle Esser ${ }^{4}$ and Abdelaziz Abbad
}

\begin{abstract}
Background: A literature review revealed heavy reliance on a few key publications for identification of medicinal plant species from local or vernacular names and a lack of citation of voucher specimens in many publications. There is a need for more reliable and standardized data on the identity of species used for medicine, especially because local names vary from region to region. This is especially true in the case of medicinal roots, for which identification of species is difficult. This paper contributes to existing data on the species sold as medicinal roots (and other underground plant parts such as bulbs, corms, rhizomes and tubers) in Morocco.
\end{abstract}

Methods: Data were collected in collaboration with herbalists in Marrakech and collectors in rural regions near Marrakech where species are collected from the wild. The ethno-medicinal uses of these species were also recorded.

Results: We identified the vernacular names for 67 medicinal roots (by free listing) used to treat a variety of human diseases. We were able to collect and identify one or more species for 39 of the recorded vernacular names. The ones we were not able to identify were either imported or no longer available in the markets. We collected more than one species for some of the vernacular names for a total of 43 species. We identified six new vernacular names and four species which had not been previously described in the literature. Our botanical identification matched at least one of the names listed in the literature $63 \%$ of the time and did not match any species listed in the literature $37 \%$ of the time. Of the three most commonly cited pieces of literature we compared to, we found the greatest overlap with the broader, more comprehensive work of Bellakhdar 1997 (as opposed to Benchâabane and Abbad 1997 which worked in a similarly focused geographical area). However there was only 63\% agreement between Bellakhdar 1997 and our botanical identifications, and 29\% of the time our identification didn't match even the genus of any of the species listed in any of the 3 most commonly cited pieces of literature.

Conclusions: More rigorous methodology and reporting are needed for medicinal plant research in Morocco. This will ensure that studies are comparable, help to protect traditional medicine users from negative health effects, and, support efforts to conserve overharvested wild medicinal plants.

Keywords: Medicinal plant, Root, Voucher, Herbalist, Collector, Ethnobotany, Marrakech

\footnotetext{
* Correspondence: ouarghidi@hotmail.com

'University of Cadi Ayyad, Marrakech, Morocco

${ }^{2}$ Global Diversity Foundation, Marrakech, Morocco

Full list of author information is available at the end of the article
} 
Résumé: Une revue de la littérature a révélé que l'identification des plantes médicinales (à partir des noms vernaculaires locaux) reste dépendante d'un nombre limités de publications. Une standardisation et une mise en place d'une base de données plus fiable sur l'identité des plantes médicinales utilisées en médecine deviennent un besoin incessant; d'autant plus que les noms locaux peuvent varier d'une région à l'autre. Cela est particulièrement vrai pour les espèces dont les parties souterraines sont utilisées. Cette étude vise à contribuer aux données existantes sur les espèces commercialisées sous forme de racines médicinales (et autres organes souterrains des plantes) dans les marchés de Marrakech.

Méthodes: Les données ont été collectées en collaboration avec les herboristes et les collecteurs à Marrakech et dans plusieurs de ses régions limitrophes où les espèces ont été collectées dans leur milieu naturel. L'utilisation ethno-médicinale locale pour chaque espèce médicinale a été enregistrée.

Résultats: Nous avons inventorié (par la liste libre) les noms vernaculaires correspondant à 67 racines médicinales utilisées pour traiter une panoplie de maladies humaines. Une ou plusieurs espèces végétales ont été collectées et identifiées correspondant à 39 des noms vernaculaires des racines inventoriés. Les espèces que nous n'étions pas en mesure d'identifier étaient essentiellement soit importées ou ne sont plus disponibles sur le marché. Six noms vernaculaires et quatre espèces végétales, qui n'avaient jamais été précédemment décrits dans la littérature, ont été identifiés pour la première fois dans ce travail. L'identification botanique rapportée dans ce travail correspondait à 63\% des noms des espèces énumérées dans la littérature et inversement diffère de 37\% de ceux précédemment décrits. L'analyse comparative avec les trois littératures les plus fréquemment citées, a montré une grande concordance avec Bellakhdar (1997), considéré comme le travail le plus complet (par opposition à Benchaâbane et Abbad (1997) qui ont travaillé dans la même zone géographique). Toutefois, cette concordance entre notre identification botanique et celle de Bellakhdar (1997) n'était que de 63\%, alors que 29\% des cas nous n'avons pas trouvé une correspondance même au niveau des genres des espèces décrites par les trois littératures les plus fréquemment citées.

Conclusions: Plus de méthodologie rigoureuse et de publications sont nécessaires pour la recherche en plantes médicinales au Maroc. II parait évident que l'identification botanique des échantillons provenant de différentes régions du pays soutiendra le développement d'une base de données plus fonctionnelle des plantes médicinales et de leurs noms vernaculaires locaux.

Mots clés: Plantes médicinales, Racines, Voucher, Herboriste, Collecteur, Ethnobotanique, Marrakech

\section{Background}

During the last decade, medicinal plants and their products have attracted world-wide interest due to the growing recognition of natural products and the potential for drug discovery [1]. Many populations rely on medicinal plants because they are easily available at an affordable price. Morocco has high cultural diversity, a rich traditional medical system and associated traditional knowledge, and high rates of biodiversity which provide a diversity of medicinal plants. It has been estimated that approximately 7000 plant species and sub-species grow wild in Morocco, 950 of which are endemic [2,3]. Among these, many species are aromatic or medicinal plants and are used locally in Morocco's rich and widely used traditional medicine system. It has been estimated that about 231 local plant species present phytotherapeutic properties used by the local population to treat a variety of diseases $[4,5]$.

Subterranean or underground organs of medicinal plants locally referred to as laaroug which means "roots" in Moroccan Arabic, play a central role in the Moroccan pharmacopoeia. One third of plant materials used in Moroccan traditional medicine is derived from underground organs [6] such as roots, bulbs, tubercles, and rhizomes (henceforth referred to as roots). Most of these are sold in herbal market stalls in a dried state which makes identification very difficult. Previous research has shown that both lay people and experts have more difficulty identifying medicinal roots than most other plant parts [7] and that not all herbalists have the necessary skill to identify medicinal root species accurately.

There is a large and growing body of research on medicinal plants and their pharmacological properties in Morocco. However, much of this research is hindered by reliance on previous publications to identify species from a given local (or vernacular) name. This problem is exacerbated by the fact that many medicinal plants species have multiple local names to describe them, and, inversely, local names can refer to multiple species $[1,8]$. In order to support future research and enhance research accuracy, it is necessary to establish a better and more reliable knowledge base of the identity of medicinal species, especially those used for their roots which are particularly prone to confusion. The present paper presents a brief 
literature review highlighting the need for additional primary botanical identification of medicinal plants in Morocco followed by the botanical identity and ethnomedicinal uses of species used for their roots, collected from the wild in southern Morocco and sold in the markets of Marrakech.

\section{Methods}

\section{Study area}

This paper includes a literature review from research conducted across Morocco (Figure 1). The roots identified in our botanical work were all reported to be sold in the herbal markets of Marrakech by herbalists and collected in surrounding rural regions (Figures 2 and 3). The seven rural collection sites, in the surrounding plains and the High Atlas Mountains, were between 10 and $240 \mathrm{~km}$ from Marrakech (Larbaa Tighdouine, Oukaimden, Touama, Tadart, Ait M'hamed, Sebt Aguerferouane, Ben Guerir, Asni, Tensift, and were in Marrakech and Azilal provinces (7 and 12 on the map in Figure 1). The collection site ecosystems were arid to semi-arid, similar to others found around the Mediterranean basin. These ecosystems are characterized by a rich endemic flora due, in part, to geographical variation providing a variety of bio-climates and habitat heterogeneity. The seasonal harvest of wild medicinal plants provides an important source of income for participating families in rural areas. These families play an important role in the conservation and management of these resources.

\section{Literature review}

A systematic literature review was conducted on Google Scholar and Pub Med using search terms "Morocco", "Maroc", "North Africa", "Medicinal Plant", "Herbal", "Traditional Medicine" or "Ethnobotany" for papers in French or English, with no restriction on date of publication (January 2012). A hundred and thirty six potential papers were identified before applying exclusion criteria to narrow the list. Following systematic review guidelines the inclusion / exclusion criteria were set in advance by 2 researchers with the aim of including only papers that would realistically be expected to include botanical identification and vouchers. Exclusion criteria included: papers on only one species (and papers with species identified in the title), papers which looked only at pharmacological actions and papers on cultivated or food species. After excluding papers with the above criteria, 26 papers were identified, obtained, and reviewed. We looked at how researchers had identified medicinal plants: the use of botanical keys, name of the botanists who did the identification and the affiliation of the botanist or the authors involved in identification.

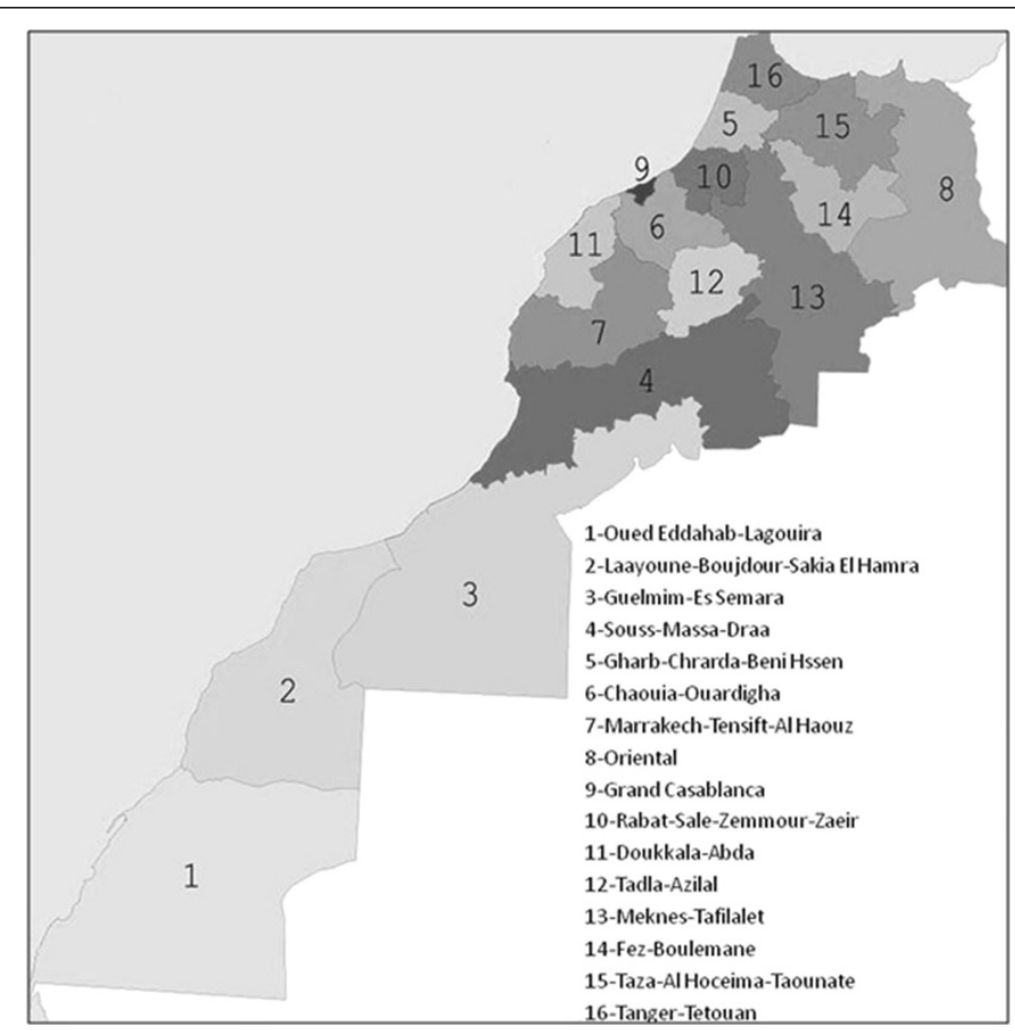

Figure 1 Map of Morocco with provinces numbered for reporting location of literature review studies (see Table 1). 


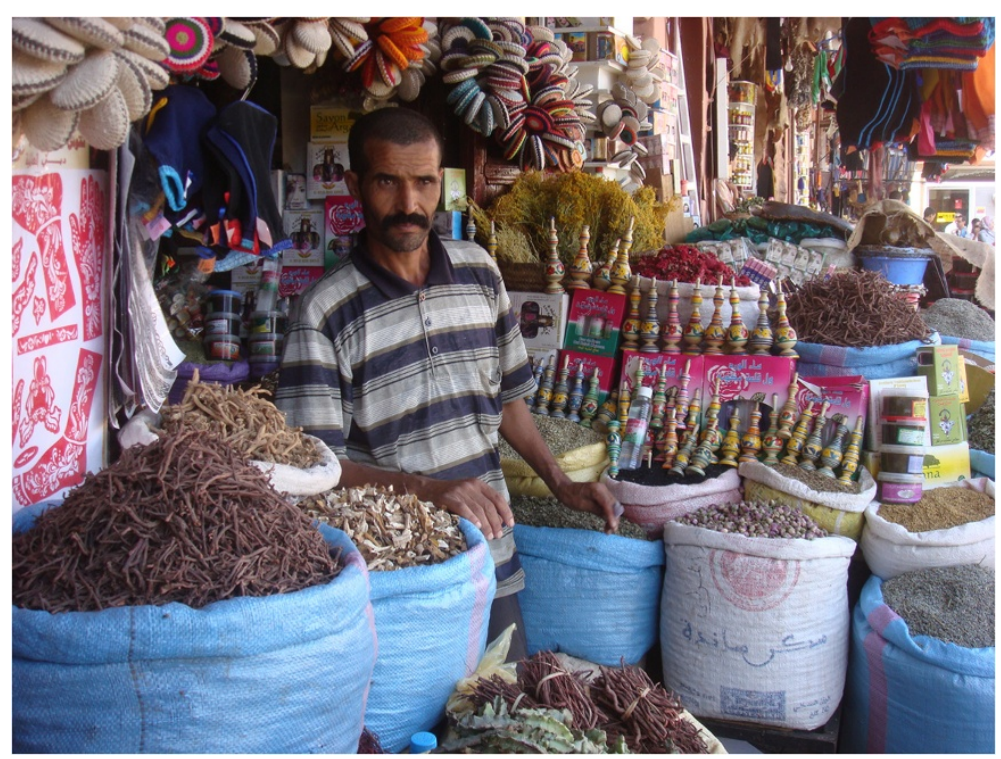

Figure 2 Bags containing single medicinal roots and herbal mixtures in the Marrakech herbal market (Photo: A. Ouarghidi).

\section{Botanical identification of local names}

Field work was undertaken from 2007-2010 to gather data on species where the root is used in traditional medicine in the markets of Marrakech. Verbal consent was obtained from all herbalists and collectors after research purposes had been explained in detail. We selected 15 herbalists who were the most knowledgeable about medicinal roots, based on our previous extensive work. These 15 herbalists were asked to list all the medicinal roots traded in southern Morocco. Together they identified 67 medicinal roots (and subterranean plant parts) by their local or vernacular names. These roots were then traced through the market chain to various collection sites in rural areas surrounding Marrakech. Twenty three collectors were identified and voucher specimens were collected with them during their normal collecting activities. Specimens matching local names were collected in each of the sites where collection was taking place (one or more specimens for each vernacular name). Botanical identification of plants was done by Abderrahim Ouarghidi, under the supervision of Dr Mohamed Ibn Tattou and Dr Mohamed Fennane from the Scientific Institute of Rabat (ISR). Collected vouchers were compared with specimens in the Herbarium of ISR. Flore de L'Afrique du Nord [9]

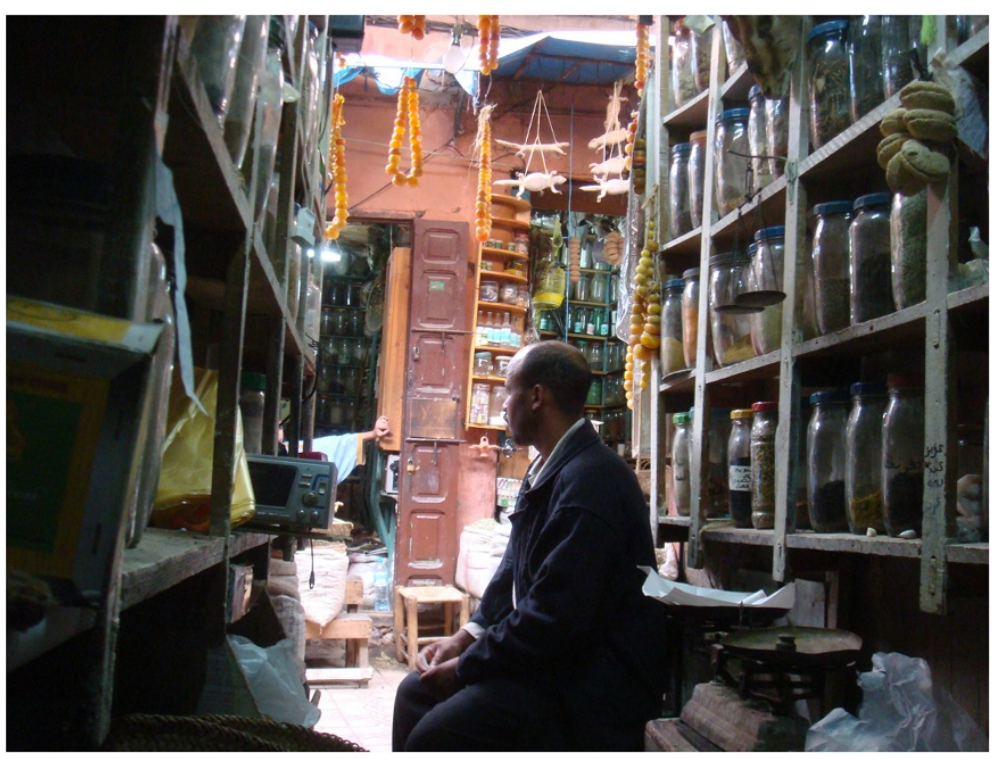

Figure 3 Herbalist's store in the Marrakech herbal market (Photo: A. Ouarghidi). 
and Petite Flore des Régions arides du Maroc occidental [10] were the botanical keys consulted during identification. Voucher specimens were deposited in the Natural History Museum of Marrakech.

\section{Comparison to species identified in the literature}

The botanical species identified for each local name were compared with those previously reported in the most commonly cited literature. The literature review identified Bellakhdar "La Pharmacopée Marociane Traditionelle: Médicine Arabe Ancienne et Savoirs Populaires" [11], Benchâabane and Abbad "Les plantes medicinales commercialisées à Marrakech" [12], and Boulos "Medicinal Plants of North Africa" [13] as the most commonly cited sources for botanical identification of vernacular names in medicinal plant research papers from Morocco (on Google Scholar, Boulos [13] appears as cited 319 times, Bellakhdar [11] 251 times, January 2012). We compared the species we collected to species cited for the same vernacular name by these three 'expert texts'. Because these texts do not cite voucher specimens we were not able to differentiate between incorrect identification and cases where vernacular names refer to multiple botanical species (a likely scenario as these texts cover a wide geographic region).

\section{Traditional Use information and availability}

Information was collected using structured and semistructured interviews with over 80 herbalists in Marrakech to identify the traditional uses for each medicinal root and its relative abundance (availability) in the market. Roots were classified based on availability: rare, common and abundant.

\section{Results}

Literature review of medicinal plant identification in Morocco Of the 26 papers we reviewed, $42 \%$ cited one or more botanical key used for the identification of collected species, $42 \%$ reported the name of the botanist(s) carrying out the identification, and $61.5 \%$ the botanist(s)' affiliation (Table 1). Although 58\% papers reported the collection of voucher specimens, only $35 \%$ reported voucher numbers. The remaining papers used existing literature to identify species from vernacular names, rather than using a scientific identification process. Of the provinces of Morocco (listed in Figure 1), Chaouia-Ouardigha, Grand Casablanca, DoukkalaAbda (with only one study in each), the three Saharaian provinces and Azilal (with only 2 studies in each), and Marrakech, Oriental and Fez-Boulemane (with only 3 studies in each) were the least studied provinces. MeknesTafilalet was the most studied province (with $30 \%$ of the studies we reviewed having been conducted there), followed by Rabat, Gharb, Taza-Taounate and Tanger (with 4, 5 or 6 studies in each).

\section{Identification of medicinal roots}

We identified 67 medicinal roots (by free listing of local name) used to treat a variety of human diseases. Nine vernacular names appeared on the free lists of at least 10 of the 15 herbalists interviewed. More than $35 \%$ of vernacular names appeared on 2 or fewer of the herbalists' free lists. Medicinal uses listed were diverse, including: rheumatism, cold, gaining weight, aphrodisiac, female reproductive ailments, stomach and intestine problems, skin diseases, and hair problems (Table 2).

Of the 67 vernacular names recorded in the free lists, 57 were included for further analysis (Table 2) based on subsequent discussion with herbalists which revealed 10 remedies that were listed in a single free list but not confirmed by other herbalists (defla, delya, jebouj, kalyptus, zitoun, klikha, louya, n'khal) or that were common culinary species (skenjbir (Zingiber officinale Roscoe), kherqoum beldi (Curcuma sp)). Two additional vernacular names were identified though work with collectors (Table 2). We were able to collect and identify one or more species for 39 of the recorded vernacular names. The other 20 were not available for collection: reported by herbalists to be rare, extinct or imported.

We collected more than one species for 5 of the 39 vernacular names (awedmi, azalim n'ouchen, deryass, serghina/tasserghint and tiguendizt), one species collected under two different vernacular names (Ammoides pusilla (Brot.) Beistr. was collected as amssekhsser and bouzfour) and two varieties of Anacyclus pyrethrum were collected, resulting in a total of 43 species identified.

Of the underground plant parts collected for identification $92 \%$ were roots, $4 \%$ were rhizomes, $4 \%$ were bulbs. Asteraceae ( 9 species), Apiaceae ( 8 species) and Caryophyllaceae (4 species) plant families contained the highest number of species, with the remaining families containing 3 or fewer species each (Table 2).

\section{Comparison to the literature}

We identified six new vernacular names (belhdar, tizgha, baguremane, ghartague, nedkhir, tizorin) which, to our knowledge, had not previously been reported in the literature as being used medicinally in Morocco (Table 2). Of the medicinal roots listed by vernacular names in Table 2, 17 (29\%) had not been identified botanically in the literature. We identified 4 of these: bougoudz (Tamus communis L.), ghazghaz (Carlina brachylepis (Batt.) Meusel \& Kästner), tizorin (Valeriana tuberosa L.) and temt (Carthamus pinnatus Desf.). Of the 42 vernacular names in Table 2 which had botanical identification listed in the most commonly cited literature, 25 of these had 2 or more species listed. Up to 5 species were reported for a single vernacular name (s'koum), with an average of 2.21 species listed per vernacular name. Of the 39 vernacular names we identified, at least one of 
Table 1 Summary of 26 papers on medicinal plants in Morocco including methods used for botanical identification (use of a botanical key, name of the botanist, institution of the botanist or authors and number of species identified)

\begin{tabular}{|c|c|c|c|c|c|c|c|c|}
\hline Paper & Methodology & Keys & Botanists & Institutions & $\begin{array}{l}\text { Voucher } \\
\text { mentioned }\end{array}$ & $\begin{array}{l}\text { Voucher } \\
\mathrm{N}^{\circ} \\
\text { reported }\end{array}$ & $\begin{array}{l}\text { Number of } \\
\text { Plant } \\
\text { Species } \\
\text { Identified }\end{array}$ & Study area \\
\hline $\begin{array}{l}\text { Bellakhdar } \\
\text { et al. [4] }\end{array}$ & $\begin{array}{l}\text { Interviews and specimen collection with } \\
\text { traditional healers }\end{array}$ & Yes & Yes & Yes & Yes & Yes & 231 & $\begin{array}{l}1,2,3,4,5,6 \\
7,8,9,10,11 \\
12,13,14,15 \\
16\end{array}$ \\
\hline $\begin{array}{l}\text { Benkhnigue } \\
\text { et al. [14] }\end{array}$ & $\begin{array}{l}\text { Ethnobotanical investigations, based on } 280 \\
\text { interviews, conducted during two periods in } \\
2006 \text { and } 2007 \text {. }\end{array}$ & Yes & No & No & No & No & 149 & 5 \\
\hline $\begin{array}{l}\text { Eddouks } \\
\text { et al. [15] }\end{array}$ & $\begin{array}{l}\text { Ethnobotanical information was obtained from } \\
280 \text { local residents. }\end{array}$ & No & Yes & Yes & Yes & Yes & 92 & 13 \\
\hline $\begin{array}{l}\text { El Amrani } \\
\text { et al. [16] }\end{array}$ & $\begin{array}{l}\text { Ethnobotanical study carried out with } \\
\text { herbalists, traditional healers and patients. } \\
\text { Samples were purchased from herbalists stores. }\end{array}$ & No & No & No & No & No & 42 & 13 \\
\hline $\begin{array}{l}\text { El Mansouri } \\
\text { et al. [17] }\end{array}$ & $\begin{array}{l}\text { Samples of plants used locally were harvested } \\
\text { on land and/or requested from herbalists. }\end{array}$ & Yes & No & No & No & No & 109 & 13 \\
\hline $\begin{array}{l}\text { El Rhaffari } \\
{[18]}\end{array}$ & $\begin{array}{l}\text { Ethnobotanical study carried out with } \\
\text { herbalists, traditional healers and patients } \\
\text { (leishmaniose cutanée) }\end{array}$ & Yes & No & No & Yes & No & 61 & 13 \\
\hline $\begin{array}{l}\text { El Rhaffari } \\
\text { and Zaid, } \\
{[19]}\end{array}$ & $\begin{array}{l}\text { Surveys carried out with herbalists, traditional } \\
\text { healers and consumers. }\end{array}$ & No & Yes & Yes & Yes & No & 215 & 13 \\
\hline $\begin{array}{l}\text { El-Hilaly } \\
\text { et al. [20] }\end{array}$ & $\begin{array}{l}\text { Standard Ethnobotanical survey of the } \\
\text { Taounate with (1) those who knew and/or } \\
\text { used plants for medicinal purposes and ( } 2 \text { ) } \\
\text { those who used plants and plant products for } \\
\text { commercial purposes (plant collectors, } \\
\text { wholesalers, retailers). }\end{array}$ & No & Yes & Yes & Yes & No & 102 & 15 \\
\hline $\begin{array}{l}\text { Ennabili } \\
\text { et al. [21] }\end{array}$ & $\begin{array}{l}295 \text { interviews at } 29 \text { sites using a structured } \\
\text { questionnaire form. }\end{array}$ & Yes & Yes & Yes & Yes & No & 78 & 16 \\
\hline $\begin{array}{l}\text { González- } \\
\text { Tejero et al. } \\
\text { [22] }\end{array}$ & $\begin{array}{l}\text { In Ouezanne region, } 87 \text { Semi-structured } \\
\text { interviews and participant observation of } 72 \\
\text { informants. }\end{array}$ & Yes & Yes & Yes & Yes & No & 100 & 5 \\
\hline $\begin{array}{l}\text { Hseini et al. } \\
{[23]}\end{array}$ & $\begin{array}{l}\text { An inventory of medicinal plants was carried } \\
\text { out in the region of Rabat with traditional } \\
\text { healers. }\end{array}$ & Yes & Yes & Yes & No & No & 280 & 10 \\
\hline $\begin{array}{l}\text { Jouad et al. } \\
{[24]}\end{array}$ & $\begin{array}{l}\text { Interview of } 25 \text { traditional herbal healers and a } \\
\text { total of more than } 1153 \text { patients who use } \\
\text { medicinal plants for treatment. }\end{array}$ & Yes & Yes & Yes & Yes & Yes & 90 & 14 \\
\hline $\begin{array}{l}\text { Kabbaj et al. } \\
{[25]}\end{array}$ & $\begin{array}{l}\text { Information on the anti-cancer plants used, } \\
\text { method of preparation, dosage, treatment } \\
\text { duration and observance during phytotherapy. }\end{array}$ & No & No & No & No & No & 55 & 10 \\
\hline $\begin{array}{l}\text { Khabbach } \\
{[26]}\end{array}$ & $\begin{array}{l}\text { 1) Survey of } 291 \text { of the local population } \\
\text { interviewees, 2) Field verification surveying }\end{array}$ & Yes & Yes & Yes & No & No & 140 & 15 \\
\hline $\begin{array}{l}\text { Lahsissene } \\
\text { and } \\
\text { Kahouadji } \\
{[27]}\end{array}$ & $\begin{array}{l}\text { Two ethnobotanical surveys were carried out } \\
\text { with the local community of the Zaër area } \\
\text { (2002-2003 et 2003-2004). }\end{array}$ & No & No & No & No & Yes & 228 & 10 \\
\hline $\begin{array}{l}\text { Lahsissene } \\
\text { et al., [28] }\end{array}$ & $\begin{array}{l}\text { Ethnobotanical study carried out with } \\
\text { traditional healers, herbalists and users of } \\
\text { medicinal plants. }\end{array}$ & Yes & No & Yes & No & No & 228 & 10 \\
\hline $\begin{array}{l}\text { Larhsini } \\
\text { et al. [29] }\end{array}$ & $\begin{array}{l}12 \text { plant species selected for testing based on } \\
\text { folk-medicine reports }\end{array}$ & No & No & No & No & No & 12 & Not reported \\
\hline $\begin{array}{l}\text { Larhsini } \\
\text { et al. [30] }\end{array}$ & $\begin{array}{l}\text { Plants were collected in the south of Morocco. } \\
\text { Antipyretic activity of three medicinal species. }\end{array}$ & No & No & Yes & Yes & Yes & 3 & 4 \\
\hline
\end{tabular}


Table 1 Summary of 26 papers on medicinal plants in Morocco including methods used for botanical identification (use of a botanical key, name of the botanist, institution of the botanist or authors and number of species identified) (Continued)

\begin{tabular}{|c|c|c|c|c|c|c|c|c|}
\hline Paper & Methodology & Keys & Botanists & Institutions & $\begin{array}{l}\text { Voucher } \\
\text { mentioned }\end{array}$ & $\begin{array}{l}\text { Voucher } \\
\mathrm{N}^{\circ} \\
\text { reported }\end{array}$ & $\begin{array}{l}\text { Number of } \\
\text { Plant } \\
\text { Species } \\
\text { Identified }\end{array}$ & Study area \\
\hline $\begin{array}{l}\text { Markouk } \\
\text { et al. [31] }\end{array}$ & $\begin{array}{l}\text { Plant materials were authenticated by a single } \\
\text { academic expert and were then tested for } \\
\text { insect repellent abilities by separating specific } \\
\text { substrates such as leaves or aqueous extracts }\end{array}$ & $\mathrm{No}$ & $\mathrm{No}$ & Yes & Yes & Yes & 4 & $4,10,12$ \\
\hline $\begin{array}{l}\text { Mehdioui } \\
\text { and } \\
\text { Kahouadji } \\
\text { [32] }\end{array}$ & $\begin{array}{l}\text { Interviews were carried out with local } \\
\text { community of Imi n'Tlit. }\end{array}$ & No & No & No & No & No & 42 & 7 \\
\hline $\begin{array}{l}\text { Merzouki } \\
\text { et al. [33] }\end{array}$ & $\begin{array}{l}\text { Each plant species was identified by } \\
\text { Ethnobotanical survey/collection of plants local } \\
\text { herbalists and uses were indexed interviews } \\
\text { with } 785 \text { persons }\end{array}$ & No & No & Yes & Yes & Yes & 186 & 16 \\
\hline $\begin{array}{l}\text { Mouhajir } \\
\text { et al. [34] }\end{array}$ & $\begin{array}{l}\text { The plants were collected in several regions of } \\
\text { Morocco in the summers (Atlas \& Rif Mountains } \\
\text { and Sahara) of1997-2000. }\end{array}$ & $\mathrm{No}$ & $\mathrm{No}$ & Yes & Yes & No & 75 & $\begin{array}{l}1,2,3,4,5,7 \\
8,13,14,15\end{array}$ \\
\hline $\begin{array}{l}\text { Salhi et al. } \\
\text { [35] }\end{array}$ & $\begin{array}{l}\text { Ethnobotanical survey carried out with the } \\
\text { local community. }\end{array}$ & $\mathrm{No}$ & No & No & No & No & 55 & 5 \\
\hline $\begin{array}{l}\text { Sqalli et al. } \\
\text { [36] }\end{array}$ & $\begin{array}{l}31 \text { species were collected for assessing their } \\
\text { Antimycobacterien effect. }\end{array}$ & No & No & No & Yes & No & 31 & 16 \\
\hline $\begin{array}{l}\text { Tahraoui } \\
\text { et al. [37] }\end{array}$ & $\begin{array}{l}\text { Ethno-pharmacological survey given to } 400 \\
\text { who knew about and/or had used medicinal } \\
\text { plants, including suppliers and vendors }\end{array}$ & Yes & Yes & Yes & Yes & Yes & 64 & 13 \\
\hline $\begin{array}{l}\text { Ziyyat et al. } \\
\text { [38] }\end{array}$ & $\begin{array}{l}\text { Interviews were carried out with people } \\
\text { suffering, both diabetes and high blood } \\
\text { pressure }\end{array}$ & No & Yes & Yes & Yes & Yes & 42 & 8,15 \\
\hline
\end{tabular}

the species we identified matched at least one of the names listed in the literature for 25 cases (64\%); none of the species we collected matched any of the species listed in literature for 10 cases (26\%); and there were no species listed in the literature for 4 cases (Table 2).

We were able to compare our 45 botanical identifications (43 species) to the species listed for their corresponding vernacular names in the literature for 41 cases (due to 4 not being previously identified). Our botanical identification matched at least one of the names listed in the literature $63 \%$ of the time (26 cases) and did not match any species listed in the literature $37 \%$ of the time (15 cases). There were 3 cases where the genus but not the species matched between the species we collected and those listed in the literature. Our botanical identification matched at least the genus of at least one of the names listed in the literature $71 \%$ of the time (29 cases); $29 \%$ of the time our identification did not match even the genus of any of the species listed in the literature (Table 2).

The three most commonly cited literature works we compared to were: Bellakhdar 1997 "La Pharmacopée Marociane Traditionelle: Médicine Arabe Ancienne et Savoirs Populaires" [11], Benchâabane and Abbad 1997 "Les plantes medicinales commercialisées à Marrakech"
[12], and Boulos 1983 "Medicinal Plants of North Africa" [13]. Of our 45 botanical identification, 91\% (41 cases) were listed by Bellakhdar 1997 and 64\% (29 cases) each by Boulos 1983 and Benchâabane and Abbad 1997. Of the names provided by each, 63\% (26 matches of the 41 listed) of the identifications provided by Bellakhdar 1997, 58.6\% (17 matches of the 29 listed) of the identifications provided by Boulos 1983, and 55.2\% (16 matches of the 29 listed) of those provided by Benchâabane and Abbad 1997 agreed with our identifications (Table 2). Considering these differing rates of agreement from a geographical perspective, we note that Bellakhdar 1997 covered all of Morocco, the broadest geographical region, Boulos 1983 worked in 13 of the provinces listed in Figure 1 (all of Morocco except the 3 most southerly provinces) and Benchâabane and Abbad 1997 worked only in Marrakech region (7 in Figure 1). Our study was conducted mainly in Marrakech and Azilal provinces (7 and 12 in Figure 1). There is thus geographical overlap between our study and each of the 3 most commonly used pieces of literature. Rather than seeing greater overlap in the work from a similarly focused geographic area (Benchâabane and Abbad 1997), we found the greatest overlap with the broader, more comprehensive work of Bellakhdar 1997. This may 
Table 2 List of medicinal roots and their ethno-medicinal uses in Marrakech region (in order of frequency on 15 herbalists' free lists)

\begin{tabular}{|c|c|c|c|c|c|c|c|}
\hline $\begin{array}{l}\text { Vernacular } \\
\text { names }\end{array}$ & Botanical identification & Family & Voucher & Frequency & Uses & $\begin{array}{l}\text { Reported } \\
\text { availability }\end{array}$ & $\begin{array}{l}\text { Other scientific names } \\
\text { listed in the literature }\end{array}$ \\
\hline \multirow[t]{3}{*}{ Foua } & \multirow[t]{3}{*}{ Rubia peregrina $\mathrm{L}$. } & \multirow[t]{3}{*}{ Rubiaceae } & \multirow[t]{3}{*}{$795 \mathrm{~A}$} & \multirow[t]{3}{*}{12} & \multirow{3}{*}{$\begin{array}{l}\text { Hepatitis, Liver } \\
\text { problems, Tonic, } \\
\text { Gain weight }\end{array}$} & \multirow[t]{3}{*}{ Common } & Rubia peregrina $L^{\mathrm{a}, \mathrm{b}, \mathrm{c}}$ \\
\hline & & & & & & & Rubia tinctorum $\mathrm{L}^{\mathrm{a}, \mathrm{b}, \mathrm{c}}$ \\
\hline & & & & & & & Galium odoratum (L.) Scop.b \\
\hline $\begin{array}{l}\text { Serghina } \\
\text { (Tasserghint) }\end{array}$ & $\begin{array}{l}\text { Petrorhagia illyrica (Ard.) P.W. } \\
\text { Ball \& Heywood, Corrigiola } \\
\text { telephiifolia Pourret }\end{array}$ & Caryophyllaceae & $\begin{array}{l}866 A \\
867 A\end{array}$ & 12 & $\begin{array}{l}\text { Gain weight, } \\
\text { Appetizer, } \\
\text { Incense, } \\
\text { Headache, } \\
\text { Migraine }\end{array}$ & Common & $\begin{array}{l}\text { Corrigiola telephiifolia } \\
\text { Pourret }^{a, b, c}\end{array}$ \\
\hline \multirow{3}{*}{$\begin{array}{l}\text { Kherchouf } \\
\text { (Kherchouf } \\
\text { Beldi) }\end{array}$} & \multirow[t]{3}{*}{ Cynara cardunculus L. } & \multirow[t]{3}{*}{ Asteraceae } & \multirow[t]{3}{*}{$470 \mathrm{~K}$} & \multirow[t]{3}{*}{11} & \multirow[t]{3}{*}{ Abdominal pain } & \multirow[t]{3}{*}{ Common } & Cynara cardunculus L. ${ }^{\mathrm{a}, \mathrm{b}, \mathrm{c}}$ \\
\hline & & & & & & & Cynara humilis L.' \\
\hline & & & & & & & Cynara scolymus L.' \\
\hline L'guseb & Phragmites communis Trin. & Poaceae & $836 \mathrm{~A}$ & 11 & Hair problems & Common & $\begin{array}{l}\text { Phragmites communis Trin. } \\
\text { Phragmites australis } \\
\text { (Cav.) Trin. Ex Steud. } \\
\text { Arundo donax L. }\end{array}$ \\
\hline Bereztem & $\begin{array}{l}\text { Aristolochia paucinervis } \\
\text { Pomel }\end{array}$ & Aristolochiaceae & $797 \mathrm{~A}$ & 11 & Aorta palpitation & Common & $\begin{array}{l}\text { Aristolochia baetica } \mathrm{L}^{\mathrm{a}} \\
\text { Aristolochia longa } \mathrm{L} . \mathrm{a}, \mathrm{c}\end{array}$ \\
\hline Fouilia & NA & NA & NA & 11 & Fractures & Common & - \\
\hline Tasskra & $\begin{array}{l}\text { Echinops spinosissimus subsp. } \\
\text { fontqueri (Pau) Greuter }\end{array}$ & Asteraceae & $478 \mathrm{~K}$ & 10 & $\begin{array}{l}\text { Rheumatism, } \\
\text { Colds, Female } \\
\text { reproductive } \\
\text { ailments }\end{array}$ & Common & $\begin{array}{l}\text { Echinops spinosissimus subsp. } \\
\text { fontqueri (Pau) Greuter } a, b, c\end{array}$ \\
\hline \multirow{4}{*}{$\begin{array}{l}\text { Ouden } \\
\text { helouf }\end{array}$} & \multirow[t]{4}{*}{ Pulicaria odora (L.) Reichenb. } & \multirow[t]{4}{*}{ Asteraceae } & \multirow[t]{4}{*}{$806 \mathrm{~A}$} & \multirow[t]{4}{*}{10} & \multirow{4}{*}{$\begin{array}{l}\text { Gain weight, } \\
\text { Sterility }\end{array}$} & \multirow[t]{4}{*}{ Common } & Ranunculus bullatus L. ${ }^{a, c}$ \\
\hline & & & & & & & $\begin{array}{l}\text { Ranunculus macrophyllus } \\
\text { Desf., }\end{array}$ \\
\hline & & & & & & & Ranunculus muricatus $\mathrm{L}^{\mathrm{a}, \mathrm{C}}$ \\
\hline & & & & & & & Ranunculus arvensis $\mathrm{L}^{\mathrm{a}}$ \\
\hline Addad & Carlina gummifera (L.) Less. & Asteraceae & $835 \mathrm{~A}$ & 10 & $\begin{array}{l}\text { Acne, Pruritus, } \\
\text { Fumigation }\end{array}$ & Rare & Atractylis gummifera L. ${ }^{a, b, c}$ \\
\hline Bekbouka & Bunium bulbocastanum L. & Apiaceae & $92 \mathrm{~A}$ & 9 & Gain weight & Rare & Colchicum autumnale $L$. \\
\hline \multirow[t]{4}{*}{ Amssekhsser } & \multirow{4}{*}{$\begin{array}{l}\text { Ammoides pusilla (Brot.) } \\
\text { Beistr. }\end{array}$} & \multirow[t]{4}{*}{ Apiaceae } & \multirow[t]{4}{*}{$794 \mathrm{~A}$} & \multirow[t]{4}{*}{9} & \multirow[t]{4}{*}{ Incense } & \multirow[t]{4}{*}{ Rare } & Polygonum aviculare L. ${ }^{a}$ \\
\hline & & & & & & & Polygonum equisetiforme S.M. ${ }^{a}$ \\
\hline & & & & & & & Polygonum maritimum L. ${ }^{a}$ \\
\hline & & & & & & & Daucus crinitus Desf. ${ }^{a}$ \\
\hline Harmel & Peganum harmala L. & Zygophyllaceae & $837 \mathrm{~A}$ & 9 & Rheumatism & Common & Peganum harmala L. $a, b, c$ \\
\hline N'jem & Cynodon dactylon (L.) Pers. & Poacese & $838 \mathrm{~A}$ & 8 & $\begin{array}{l}\text { Cold, Diuretic, } \\
\text { Bladder infection }\end{array}$ & Common & Cynodon dactylon (L.) Pers. ${ }^{a, b, c}$ \\
\hline Tafgha & Rhaponticum acaule L. & Asteraceae & $842 \mathrm{~A}$ & 8 & $\begin{array}{l}\text { Stomach } \\
\text { problems }\end{array}$ & Common & $\begin{array}{l}\text { Centaurea } \\
\text { chamaerhaponticum Bail. }\end{array}$ \\
\hline \multirow[t]{3}{*}{ Tiguendizt } & \multirow{3}{*}{$\begin{array}{l}\text { Anacyclus pyrethrum var. } \\
\text { pyrethrum Catannanche } \\
\text { caerulea L., Anacyclus } \\
\text { pyrethrum var. depressus } \\
\text { (Ball) Maire }\end{array}$} & Asteraceae & $872 \mathrm{~A}$ & 7 & Stomach & Rare & Anacyclus pyrethrum (L.) \\
\hline & & & $805 \mathrm{~A}$ & & $\begin{array}{l}\text { problems, Cnest } \\
\text { pain, }\end{array}$ & & \\
\hline & & & $873 \mathrm{~A}$ & & Rheumatism & & \\
\hline Ziyata & NA & NA & NA & 6 & Oral infection & Common & $\begin{array}{l}\text { Limoniastrum guyonianum } \\
\text { C.D. }{ }^{\circledR}\end{array}$ \\
\hline & & & & & & & $\begin{array}{l}\text { Limoniastrum ifniense (Caball.) } \\
\text { F.-Q. }{ }^{a}\end{array}$ \\
\hline & & & & & & & Polygonum maritimum $\mathrm{L}^{\mathrm{a}, \mathrm{b}}$ \\
\hline
\end{tabular}


Table 2 List of medicinal roots and their ethno-medicinal uses in Marrakech region (in order of frequency on 15 herbalists' free lists) (Continued)

\begin{tabular}{|c|c|c|c|c|c|c|c|}
\hline $\begin{array}{l}\text { Vernacular } \\
\text { names }\end{array}$ & Botanical identification & Family & Voucher & Frequency & Uses & $\begin{array}{l}\text { Reported } \\
\text { availability }\end{array}$ & $\begin{array}{l}\text { Other scientific names } \\
\text { listed in the literature }\end{array}$ \\
\hline Ghazghaz & $\begin{array}{l}\text { Carlina brachylepis (Batt.) } \\
\text { Meusel \& Kästner }\end{array}$ & Asteraceae & $791 \mathrm{~A}$ & 6 & $\begin{array}{l}\text { Coughing, Chest } \\
\text { pain }\end{array}$ & Common & - \\
\hline Deryass & $\begin{array}{l}\text { Thapsia villosa L. Thapsia } \\
\text { transtagana Brot. }\end{array}$ & Apiaceae & $\begin{array}{l}790 A \\
465 \mathrm{KGh}\end{array}$ & 6 & $\begin{array}{l}\text { Aphrodisiac, } \\
\text { Gain weight, } \\
\text { Colds, Incense }\end{array}$ & Abundant & $\begin{array}{l}\text { Thapsia garganica } L^{a, b, c} \\
\text { Thapsia villosa } L^{a}{ }^{a}\end{array}$ \\
\hline Bllalourz & $\begin{array}{l}\text { Asphodelus cf. microcarpus } \\
\text { Parl. }\end{array}$ & Asphodelaceae & $475 K$ & 6 & $\begin{array}{l}\text { Gain weight, } \\
\text { Skin disease, } \\
\text { Rheumatism, } \\
\text { Colds }\end{array}$ & Abundant & $\begin{array}{l}\text { Asphodelus cf. microcarpus } \\
\text { Parl. }{ }^{a, c} \\
\text { Asphodelus ramosus L. }{ }^{a} \\
\text { Asphodelus aestivus Brot. } \\
\text { Asphodelus cerasifer J.Gay. }\end{array}$ \\
\hline Kelkh & Ferula communis L. & Apiaceae & $840 A$ & 5 & $\begin{array}{l}\text { Sterility, Gain } \\
\text { weight }\end{array}$ & Common & Ferula communis L. ${ }^{a, b, c}$ \\
\hline Bougoudz & Tamus communis L. & Dioscoraceae & $796 A$ & 5 & Skin diseases & Common & - \\
\hline Khoudenjel & NA & NA & NA & 5 & $\begin{array}{l}\text { Colds, Gain } \\
\text { Weight }\end{array}$ & Common & Alpinia officinarum Hance ${ }^{a, b, c}$ \\
\hline Taryala & NA & NA & NA & 5 & Aphrodisiac & Common & $\begin{array}{l}\text { Mandragora autumnalis } \\
\text { Bertol. } a, b, c\end{array}$ \\
\hline $\begin{array}{l}\text { Tarra } \\
\text { soudaniya }\end{array}$ & Cyperus rotundus L. & Cyperaceae & $845 \mathrm{~A}$ & 4 & Hair problems & Common & $\begin{array}{l}\text { Cyperus rotundus L. }{ }^{a, b, c} \\
\text { Cyperus longus L. }{ }^{c} \\
\text { Cyperus articulates L. }{ }^{a} \\
\text { Cyperus maculates Boeck. }\end{array}$ \\
\hline Tigheghcht & $\begin{array}{l}\text { Silene vulgaris (Moench) } \\
\text { Garcke }\end{array}$ & Caryophyllaceae & $800 A$ & 4 & $\begin{array}{l}\text { Clean wool, } \\
\text { Intestinal pains, } \\
\text { Incense, Itching }\end{array}$ & Common & $\begin{array}{l}\text { Saponaria vaccaria L. } \\
\text { Saponaria glutinosa Bieb. } \\
\text { Silene inflata Sm. }\end{array}$ \\
\hline D'bagh & $\begin{array}{l}\text { Quercus ilex L. subsp. } \\
\text { rotundifolia (Lam.) T. Morais }\end{array}$ & Fagaceae & $486 K$ & 4 & $\begin{array}{l}\text { Stomach } \\
\text { problems, Hair } \\
\text { problems, Skin } \\
\text { inflammation }\end{array}$ & Common & $\begin{array}{l}\text { Quercus ilex L. subsp. } \\
\text { rotundifolia (Lam.) T. Morais } \\
\text { Quercus suber L.c }\end{array}$ \\
\hline Awedmi & $\begin{array}{l}\text { Armeria cf. alliacea (Cav.) } \\
\text { Hoffmanns. \& Link, Meum } \\
\text { athamanticum Jacq. }\end{array}$ & Plumbaginaceae & $\begin{array}{l}802 \mathrm{~A} \\
862 \mathrm{~A}\end{array}$ & 4 & Rheumatism & Rare & $\begin{array}{l}\text { Polygonum aviculare L. } \\
\text { Polygonum equisetiforme S.M. } \\
\text { Armeria cf. alliacea (Cav.) } \\
\text { Hoffmanns. \& Link }{ }^{a} \\
\text { Armeria mauritanica Wallr. }\end{array}$ \\
\hline $\begin{array}{l}\text { Boughlam } \\
\text { sahraoui }\end{array}$ & $\begin{array}{l}\text { Spergularia marginata (DC.) } \\
\text { Kittel }\end{array}$ & Caryophyllaceae & $869 A$ & 4 & $\begin{array}{l}\text { Cold, Gain } \\
\text { weight }\end{array}$ & Rare & $\begin{array}{l}\text { Spergularia marginata (DC.) } \\
\text { Kittel }^{\text {a }}\end{array}$ \\
\hline Telh & Acacia gummifera Willd. & Mimosaseae & $846 A$ & 4 & Fumigation & Common & $\begin{array}{l}\text { Acacia gummifera Willd. } \\
\text { Acacia raddiana Savi. } \\
\text { Acacia seyal Del. }\end{array}$ \\
\hline M'ghizla & Eryngium tricuspidatum L. & Apiaceae & $793 A$ & 3 & $\begin{array}{l}\text { Gain weight, } \\
\text { Tonic, } \\
\text { Rheumatism }\end{array}$ & Common & Eryngium tricuspidatum L. ${ }^{a}$ \\
\hline $\begin{array}{l}\text { Swak } \\
\text { Raayan }\end{array}$ & NA & NA & NA & 3 & Vitiligo & Common & - \\
\hline Derdar & NA & NA & NA & 3 & Migraine & Common & - \\
\hline Bessbess & Foeniculum vulgare P. Mill & Apiaceae & $843 \mathrm{~A}$ & 3 & $\begin{array}{l}\text { Stomach } \\
\text { problems, } \\
\text { Sterility }\end{array}$ & Common & $\begin{array}{l}\text { Foeniculum vulgare P. Mill a,b,c } \\
\text { Foeniculum dulce DC. }{ }^{a}\end{array}$ \\
\hline Hedja & NA & NA & NA & 2 & Rheumatism & Common & $\begin{array}{l}\text { Citrullus colocynthis (L.) } \\
\text { Schard. } a, b, c\end{array}$ \\
\hline
\end{tabular}


Table 2 List of medicinal roots and their ethno-medicinal uses in Marrakech region (in order of frequency on 15 herbalists' free lists) (Continued)

\begin{tabular}{|c|c|c|c|c|c|c|c|}
\hline $\begin{array}{l}\text { Vernacular } \\
\text { names }\end{array}$ & Botanical identification & Family & Voucher & Frequency & Uses & $\begin{array}{l}\text { Reported } \\
\text { availability }\end{array}$ & $\begin{array}{l}\text { Other scientific names } \\
\text { listed in the literature }\end{array}$ \\
\hline Aarq sous & NA & NA & NA & 2 & $\begin{array}{l}\text { Stomach and } \\
\text { Throat problems }\end{array}$ & Common & $\begin{array}{l}\text { Glycyrrhiza glabra L. }{ }^{a, b, c}, \\
\text { Glycyrrhiza foetida Desf. }{ }^{a, c}\end{array}$ \\
\hline $\begin{array}{l}\text { Awermi } \\
\text { (Fijel) }\end{array}$ & Ruta montana L. & Rutaceae & $789 A$ & 2 & $\begin{array}{l}\text { Aphrodisiac, } \\
\text { Rheumatism, } \\
\text { Colds }\end{array}$ & Common & $\begin{array}{l}\text { Ruta montana } \text { L. }^{a, b, c}, \\
\text { Ruta chalepensis } \text { L. }^{a, b, c} \\
\text { Haplophyllum vermiculare } \\
\text { Hand. \& Maz. }{ }^{\text {a }} \\
\text { Haplophyllum tuberculatum } \\
\text { (Forssk.) A. Juss. }{ }^{b}\end{array}$ \\
\hline Boujlal & NA & NA & NA & 2 & Gain weight & Rare & - \\
\hline Soussban & NA & NA & NA & 2 & Gain weight & Common & $\begin{array}{l}\text { Iris germanica L. }{ }^{a, b, c} \\
\text { Iris florentina L. }{ }^{a} \\
\text { Iris pseudoacorus L. }{ }^{a}\end{array}$ \\
\hline Frifra & NA & NA & NA & 2 & NA & Rare & - \\
\hline S'der & Ziziphus lotus (L.) Lam. & Rhamnaceae & $489 K$ & 2 & $\begin{array}{l}\text { Stomach } \\
\text { problems, } \\
\text { Bladder } \\
\text { problems }\end{array}$ & Common & Ziziphus lotus (L.) Lam. a,b,c \\
\hline Doum & Chamaerops humilis L. & Palmaceae & $841 \mathrm{~A}$ & 2 & Aphrodisiac & Abundant & Chamaerops humilis L. ${ }^{a}$ \\
\hline Bouzfour & $\begin{array}{l}\text { Ammoides pusilla (Brot.) } \\
\text { Beistr. }\end{array}$ & Apiaceae & $474 K$ & 2 & Incense & Rare & Daucus crinitus Desf. ${ }^{a}$ \\
\hline Abu & Kundmania sicula (L.) DC. & Apiaceae & $808 \mathrm{~A}$ & 2 & $\begin{array}{l}\text { Aphrodisiac, } \\
\text { Sterility, Colds, } \\
\text { Rheumatism }\end{array}$ & Common & $\begin{array}{l}\text { Thapsia garganica L. }{ }^{a, b} \\
\text { Thapsia villosa L. }{ }^{a}\end{array}$ \\
\hline Kef saboun & NA & NA & NA & 2 & Colds & Rare & - \\
\hline Kers aanou & NA & NA & NA & 2 & $\begin{array}{l}\text { Aphrodisiac, } \\
\text { Gain weight, } \\
\text { Colds }\end{array}$ & Rare & - \\
\hline Terta & NA & NA & NA & 2 & NA & Common & - \\
\hline Belhdar & NA & NA & NA & 2 & NA & Rare & - \\
\hline S'koum & Asparagus stipularis Forsk. & Asparagaceae & $844 \mathrm{~A}$ & 2 & Aphrodisiac & Common & $\begin{array}{l}\text { Asparagus stipularis Forsk. }{ }^{\mathrm{a}, \mathrm{b}} \\
\text { Asparagus albus L. }{ }^{a} \\
\text { Asparagus acutifollius L. }{ }^{a} \\
\text { Asparagus pastorianus Webb. } \\
\text { \& Berth. }{ }^{a} \\
\text { Asparagus altissimus Munb. }{ }^{a}\end{array}$ \\
\hline R'tem & NA & NA & NA & 1 & $\begin{array}{l}\text { Incense, } \\
\text { Abortion }\end{array}$ & Rare & $\begin{array}{l}\text { Retama monosperma Boiss. } \\
\text { Retama sphaerocarpa (L.) } \\
\text { Boiss. }^{\text {a }} \\
\text { Retama retam (Forsk.) Webb. }^{\text {a }}\end{array}$ \\
\hline Tizgha & NA & NA & NA & 1 & NA & Rare & - \\
\hline Baguremane & NA & NA & NA & 1 & NA & Rare & - \\
\hline Ghartague & NA & NA & NA & 1 & NA & Rare & - \\
\hline Nedkhir & NA & NA & NA & 1 & NA & Rare & - \\
\hline Temt & Carthamus pinnatus Desf. & Asteraceae & $468 K$ & 1 & Fumigation & Common & - \\
\hline Swaka & Juglan regia $\mathrm{L}$. & Juglandaceae & $469 K$ & 1 & $\begin{array}{l}\text { Tooth care, } \\
\text { Gingivitis }\end{array}$ & Abundant & Juglan regia L. $a, b, c$ \\
\hline
\end{tabular}


Table 2 List of medicinal roots and their ethno-medicinal uses in Marrakech region (in order of frequency on 15 herbalists' free lists) (Continued)

\begin{tabular}{|c|c|c|c|c|c|c|c|}
\hline $\begin{array}{l}\text { Vernacular } \\
\text { names }\end{array}$ & Botanical identification & Family & Voucher & Frequency & Uses & $\begin{array}{l}\text { Reported } \\
\text { availability }\end{array}$ & $\begin{array}{l}\text { Other scientific names } \\
\text { listed in the literature }\end{array}$ \\
\hline Smar & Juncus maritimus Lamk. & Juncaceae & $839 A$ & 1 & $\begin{array}{l}\text { Cold, } \\
\text { Fumigation }\end{array}$ & Common & $\begin{array}{l}\text { Juncus maritimus Lamk. }{ }^{a, b, c} \\
\text { Juncus acutus L. }{ }^{a, b} \\
\text { Juncus bufonius L. }{ }^{a, b}\end{array}$ \\
\hline Saleh n'der & Verbascum sinuatum L. & Scrofulariaceae & $870 A$ & 1 & Ophthalmopathy & Common & $\begin{array}{l}\text { Verbascum sinuatum L. }{ }^{a, b} \\
\text { Verbascum thapsiforme Scrad }{ }^{c} \\
\text { Verbascum granatense Boiss }{ }^{\text {a }}\end{array}$ \\
\hline Tizorin & Valeriana tuberosa L. & Valerianaceae & $830 A$ & 0 & Colic & Common & 一 \\
\hline $\begin{array}{l}\text { Azalim } \\
\text { n'ouchen } \\
\text { (Aansla) }\end{array}$ & Drimia maritima (L.) Stearn, & Hyacinthaceae & $\begin{array}{l}471 \mathrm{~K} \\
882 \mathrm{~A}\end{array}$ & 0 & $\begin{array}{l}\text { Hepatitis, Black } \\
\text { magic, } \\
\text { Rheumatism, } \\
\text { Colds }\end{array}$ & Abundant & $\begin{array}{l}\text { Urginia maritime (L.) Baker }{ }^{a, b, ~ c} \\
\text { Urginia noctiflora Batt. \& Trab. }{ }^{a}\end{array}$ \\
\hline
\end{tabular}

NA: not locally available.

a. Bellakhdar [11].

b. Boulos [13].

c. Benchaabane et Abbad [12].

be due to the fact that Bellakhdar 1997 is a more comprehensive work, listing more species per vernacular name that other literature (Table 2). However there was still only 63\% agreement between Bellakhdar 1997 and our botanical identifications, and $29 \%$ of the time our identification didn't match even the genus of any of the species listed in the literature.

\section{Discussion}

Botanical identification of remedies from roots, barks and resins remains a particularly challenging problem $[7,39]$. Several of the studies we reviewed that examined at the pharmacological and physiological function of species, had based the botanical identity of their species on identification from vernacular names using previous literature. This study has shown major inconsistencies in this method, rendering the above studies incomparable to any past or future studies.

Difficulty in identifying medicinal roots poses a problem not only to scientific research but also to local traditional medicine practitioners, who need to be able to identify roots to ensure effective and safe treatment of their clients. Poor identification of medicinal roots by both scientific research and local herbalists has a number of important implications.

There is increasing controversy surrounding substitution and adulteration of medicinal roots traded in the herbal markets of Morocco [40]. Poor identification of medicinal roots also has implications for toxicology and public health policy. Poisoning can occur due to misidentification by local practitioners, and the ability of scientists and public health officials to deal with poisoning cases is impaired when the scientific literature is inaccurate [40]. For instance, in the most commonly used literature, bekbouka is reported to be Colchicum autumnale L. (a highly toxics species that might lead to health complications if misused $[4,41]$ ), but we identified it as Bunium bulbocatanum L. Our molecular bar-coding work has identified extensive substitution of Thapsia spp. (reported as toxic by Bellakhdar) for multiple other roots [11,44]. A relevant database of vouchered medicinal roots should be a priority for scientists to ensure adequate botanical identification and a reliable source for public health officials and future research.

Many of the root species used medicinally in Morocco are collected from the wild creating the potential of overharvesting. Poor or inaccurate identification complicates conservation efforts for endangered and rare species. These species are sometimes traded under different vernacular names to obscure substitution and adulteration practices or to circumvent prohibitions on their collection and trade. For example, tiguendizt has been previously described mainly as $A$. pyrethrum but we revealed the existence of two varieties which are morphologically similar. Massive wild harvest targets A. pyrethrum var. pyrethrum and little information is available on the current state of wild populations. Proper identification will help ensure protection of these natural resources.

\section{Conclusion}

Although DNA bar coding, which is emerging as a potential tool for plant identification, may prove useful to combat both problems of toxicity and overharvesting of endangered species [42], including medicinal plants used in Morocco [43,44], botanical identification remains a vital tool for research, conservation and public health and safety. In summary, a lack of voucher specimens of medicinal plants, particularly medicinal roots, means 
many studies have been dependent on the available literature which, we have shown, is not as complete as is needed. There is an urgent need for accurate botanical identification of wild medicinal plants. We identified the existence of cases where multiple species are categorized under the same vernacular name and we provide sitespecific data on botanical identity of traditional medicinal plants. Differences in knowledge (e.g. between ethnic groups), habitat, and geographic distribution can alter the local nomenclature used for naming medicinal plants. This suggests a need for further exhaustive investigation targeting botanical identification (with voucher specimens) of medicinal plants collected and used across multiple regions of Morocco. Furthermore, special attention should be given to endangered and over harvested species to ensure their sustainable use.

\section{Competing interests}

The authors declare that they have no competing interests.

\section{Authors' contributions}

All authors helped prepare the manuscript, and read and approved the final manuscript. Initial conceptualization of the larger project by GJM, AA, AO and others. $\mathrm{AO}$ and $\mathrm{BP}$ set the literature review key words and inclusion / exclusion criteria. The literature review was carried out by $\mathrm{AO}$ with help from GE. Data and specimen collection, and specimen identification by AO, Dr Mohamed Ibn Tattou and Dr Mohamed Fennane. Data synthesis by AO, with help from BP.

\section{Acknowledgements}

Thank you to Dr Mohamed Fennane and Dr Mohamed Ben Tatou from the National Center of Scientific Research for their assistance with botanical identification. We are grateful to the Natural History Museum of Marrakech for receiving and storing our voucher specimens. We are especially thankful to all collectors and herbalists who participated in this research for their assistance in voucher collection and for generously sharing their knowledge on traditional herbal medicine. We are grateful for the opportunity to collaborate on the larger project with colleagues from Global Diversity Foundation and the University of Uppsala (including Lars Björk, Hogo de Boer and Anneleen Kool). This research was funded by a SRL-MENA grant from the Swedish Research Council, Sida and Formas.

\section{Author details}

${ }^{1}$ University of Cadi Ayyad, Marrakech, Morocco. ${ }^{2}$ Global Diversity Foundation, Marrakech, Morocco. ${ }^{3}$ Centre for International Forestry Research, Bogor, Indonesia. ${ }^{4}$ University of British Columbia, Vancouver, British Columbia, Canada.

Received: 23 December 2012 Accepted: 3 August 2013

Published: 15 August 2013

\section{References}

1. Hamilton AC: Medicinal plants, conservation and livelihoods. Biodivers Conserv 2004, 13:1477-1517.

2. Benabid A: Flora and ecosystems of Morocco, Evaluation and preservation of biodiversity. Paris: Ibis press; 2000.

3. Fennane M: Propositions de zones importantes pour les plantes au Maroc. Atelier national zones importantes de plantes au Maroc: 11-12 Octobre 2004; Rabat. Rabat: Institut scientifique; 2004.

4. Bellakhdar J, Claisse R, Fleurentin J, Younos C: Repertory of standard herbal drugs in the Moroccan pharmacopoeia. J Ethnopharmacol 1991, 35:123-143.

5. Hmamouchi M: The Moroccan Medicinal and Aromatic Plants. Uses, biology, ecology, chemistry, pharmacology and toxicology. Rabat-Institute: Féddala; 1999.

6. Abbad A, Martin GJ, El Alaoui A, El Haouzi M, Ouarghidi A, Kadouiri A, Touiti F: Les racines médicinales commercialisées au Maroc: les complexes génériques et leur impact sur la conservation des espèces sauvages et la santé publique.
Presented at the International Conference of Medicinal and Aromatic plants. Morocco: Fez; 2007

7. Ouarghidi A: Eude comparative du savoir Ethnomédicinale et Ethnobotanique entre les guérisseurs et la population locale de la vallée d'Imnane (Région de Marrakech, Haut atlas). Master dissertation: Cadi Ayyad University, Biology Department; 2007.

8. Berlin B: Folk systematics in relation to biological classification and nomenclature. Annu Rev Ecol Evol Syst 1973, 4:259-271.

9. Maire R: Flore de I 'Afrique du Nord. Paris: Edition Paul lechevalier; 1952.

10. Negre R: Petite flore des Régions Arides du Maroc occidental. Paris: Centre National de la Recherche Scientifique; 1962.

11. Bellakhdar J: La Pharmacopée Marocaine Traditionnelle: Médicine Arabe Ancienne et Savoirs Populaires. Casablanca: Ibis press, édition le Fennec et Paris; 1997.

12. Benchâabane A, Abbad A: Les plantes médicinales commercialisées à Marrakech. Marrakech: Trace du présent; 1997.

13. Boulos L: Medicinal Plants of North Africa. Michigan: Algonac; 1983.

14. Benkhnigue O, Zidane L, Fadli M, Elyacoubi H, Rochdi A, Douira A: Etude ethnobotanique des plantes médicinales dans la région de Mechraâ Bel Ksiri (Région du Gharb du Maroc). Acta Bot. Barc 2010, 53:191-216.

15. Eddouks M, Maghrani M, Lemhadri A, EL Ouahidi M, Jouad H: Ethnopharmacological survey of medicinal plants used for the treatment of diabetes mellitus, hypertension and cardiac diseases in the south-east region of Morocco (Tafilalet). J Ethnopharmacol 2002, 82:97-103.

16. El Amrani F, Rhallab A, Alaoui T, El Badaoui K, Chakir S: Ethnopharmacological survey of some plants used for the treatment of diabetes in the region of Meknès-Tafilalet (Morocco). Phytothérapie 2010, 8:3161-165.

17. El Mansouri L, Ennabili A, Bousta D: Socio-economic interest and valorization of medicinal plants from the Rissani oasis (SE of Morocco). Boletín Latinoamericano y del Caribe de Plantas Medicinales y Aromáticas 2011, 10:30-45.

18. El Rhaffari U, Zaid A: Pratique de la phytothérapie dans le sud-est du Maroc (Tafilalet). Un savoir empirique pour une pharmacopée rénovée. Actes du $4^{\text {eme }}$ congrès Européen d'Ethnopharmacologie: Origine des pharmacopées traditionnelles et élaboration des pharmacopées savantes: 11-13 Mai 2000, Metz. Montpellier, France: CRD; 2002:295-304.

19. El Rhaffari L, Hammani K, Benlyas M, Zaid A: Traitement de la leishmaniose cutanée par la phytothérapie au Tafilalet. Biologie \& Santé 2002, 1:1.

20. El-Hilaly J, Hmammouchi M, Lyoussi B: Ethnobotanical studies and economic evaluation of medicinal plants in Taounate province (Northern Morocco). J Ethnopharmacol 2003, 86:149-158.

21. Ennabili A, Gharnit N, El Hamdaouni E: Inventory and social interest of medicinal, aromatic and honey-plants from Mokrisset region (NW of Morocco). Stud Bot. 2000, 19:57-74.

22. González-Tejero MR, Casares-Porcel M, Sánchez-Rojas CP, Ramiro-Gutiérrez JM, Molero-Mesa J, Pieroni A, Giusti ME, Censorii E, De Pasquale C, Della A, Paraskeva-Hadijchambi D, Hadjichambis A, Houmani Z, El-Demerdash M, El-Zayat M, Hmamouchi M, ElJohrig S: Medicinal plants in the Mediterranean area: Synthesis of the results of the project Rubia. J Ethnopharmacol 2008, 116:341-57.

23. Hseini S, Kahouadji A, Lahsissene H, Tijane M: Analyses floristique et ethnobotanique des plantes vasculaires médicinales utilisées dans la région de Rabat (Maroc occidental). Lazaroa 2007, 28:93-100.

24. Jouad H, Haloui M, Rhiouani H, El Hilaly J, Eddouks M: Ethnobotanical survey of medicinal plants used for the treatment of diabetes, cardiac and renal diseases in the North centre region of Morocco (Fez-Boulemane). J Ethnopharmacol 2001, 77:175-82.

25. Kabbaj F, Meddah B, Cherrah Y, Faouzi A: Ethnopharmacological profile of traditional plants used in Morocco by cancer patients as herbal therapeutics. Phytopharmacology 2012, 2:243-256.

26. Khabbach A: Plant Resources Use in the Province of Taza (North of Morocco). Proc Natl Acad Sci USA 2011, 4:264-273.

27. Lahsissene H, Kahouadji A: Analyse ethnobotanique des plantes médicinales et aromatiques de la flore marocaine: cas de la région de Zaër 1. Phytothérapie 2010, 8:202-9.

28. Lahsissene $H$, Kahouadji A, Tijane M, Hseini S: Catalogue des plantes médicinales utilisées dans La Région de Zaër (Maroc Occidental). Revue de Botanique Lejeunia 2009, 186:1-26.

29. Larhsini M, Oumoulid L, Lazrek HB, Wataleb S, Bousaid M, Bekkouche K, Jana M: Antibacterial activity of some Moroccan medicinal plants. Phytother Res 2001, 15:250-252. 
30. Larhsini M, Markouk M, Jaouhari JT, Bekkouche K, Lazrek HB, Jana M: The antipyretic activity of some Moroccan medicinal plants. Phytother Res 2002, 16:97-98.

31. Markouk M, Bekkouche K, Larhsini M, Bousaid M, Lazrek HB, Jana M: Evaluation of some Moroccan medicinal plant extracts for larvicidal activity. J Ethnopharmacol 2000, 73:293-297.

32. Mehdioui $R$, Kahouadji $A$ : Etude ethnobotanique auprès de la population riveraine de la forêt d'Amsittène : cas de la Commune d'Imi n'Tlit (Province d'Essaouira). Bulletin de l'Institut Scientifique, Section Sciences de la Vie 2007, 29:11-20

33. Merzouki A, Ed-derfoufi F, Molero Mesa J: Contribution to the knowledge of Rifian traditiona medecine. II: Folk medecine in Ksar Lakbir district (NW Morocco). Fitoterapia 2000, 71:278-307.

34. Mouhajir F, Hudson JB, Rejdali M, Towers GHN: Multiple antiviral activities of endemic medicinal plants used by berber peoples of Morocco. Pharm Biol 2001, 39:364-374.

35. Salhi S, Fadli M, Zidane L: Etudes floristique et ethnobotanique des plantes médicinales de la ville de Kénitra (Maroc). Lazaroa 2011, 31:133-143.

36. Sqalli H, El Ouarti A, Ennabili A, Ibnsouda S, Farah A, Haggoud A, Houari A, Iraqui M: Evaluation de L'effet Antimycobactérien des Plantes du Centre-Nord du Maroc. Bull Soc Pharm 2007, 146:271-288.

37. Tahraoui A, El-Hilaly J, Israili ZH, Lyoussi B: Ethnopharmacological survey of plants used in the traditional treatment of hypertension and diabetes in south-eastern Morocco (Errachidia province). J Ethnopharmacol 2007, 110:105-117.

38. Ziyyat A, Legssyer A, Mekhfi H, Dassouli A, Serhrouchni M, Benjelloun W: Phytotherapy of hypertension and diabetes in oriental Morocco. J Ethnopharmacol 1997, 58:45-54.

39. Stewart MJ, Steenkamp V: Toxicology of African herbal remedies. South African Ethnobotany 2000, 1:32-33.

40. Ouarghidi A, Powell B, Martin GJ, De Boer HJ, Abbad A: Species substitution in medicinal roots and possible implications for toxicity in Morocco. Econ Bot 2012, 66:370-382.

41. Charnot A: The toxicology in Morocco. Rabat: Mémoire de la Société des Sciences Naturelles du Maroc; 1945.

42. Zuo Y, Chen Z, Kondo K, Funamoto T, Wen J, Zhou S: DNA barcoding of Panax species. Planta Med 2011, 77:182-187.

43. Kool A, De Boer HJ, Krüger ̊̊, Rydberg A, Abbad AG: Molecular identification of commercialized medicinal plants in Southern Morocco. PLOS ONE 2012, 7:e39459. doi:10.1371/journal.pone.0039459.

44. Ouarghidi A: Evaluation Taxonomique des racines médicinales et impacts de l'exploitation sur leur conservation au Maroc. PhD thesis. Cadi Ayyad University, Biology Department; 2013.

doi:10.1186/1746-4269-9-59

Cite this article as: Ouarghidi et al:: Botanical identification of medicinal roots collected and traded in Morocco and comparison to the existing literature. Journal of Ethnobiology and Ethnomedicine 2013 9:59.

\section{Submit your next manuscript to BioMed Central and take full advantage of:}

- Convenient online submission

- Thorough peer review

- No space constraints or color figure charges

- Immediate publication on acceptance

- Inclusion in PubMed, CAS, Scopus and Google Scholar

- Research which is freely available for redistribution

Submit your manuscript at www.biomedcentral.com/submit
C Biomed Central 